\title{
Proceeding
}

Supplementary Issue: Winter Conferences of Sports Science. Costa Blanca Sports Science Events, 22-23 March 2021. Alicante, Spain.

\section{The effects of the COVID-19 pandemic on the training of athletes with disabilities in the 7-a-side football championship}

\author{
DANILO D'ANDREA ${ }^{1}$, GIOVANNI ESPOSITO ${ }^{1} \unlhd$, PIETRO LUIGI INVERNIZZI² \\ ${ }^{1}$ University of Salerno, Italy \\ 2University of Milan, Italy
}

\begin{abstract}
This study had as its main objective to investigate the difference in training programs carried out in athletes with disabilities practicing 7-a-side football before and after the Covid-19 pandemic. The two sporting seasons taken into consideration concerned the 2018/19 season and the 2020/2021 season. The study was conducted on ten disabled athletes belonging to a football school in Campania, Italy. The comparison between the two sports seasons is given in numerical terms by the statistical comparison of the results of the adapted motor tests concerning aerobic capacity and conditional capacities, which were administered to the athletes at the beginning and at the end of both sports seasons. From this comparison, in both seasons, minor improvements in the 2020/2021 season were found in athletes, between the entry and exit tes ts. It can be said that the consequences of the Covid-19 pandemic, concerning social distancing and the interruption of sports activities, have played a primary role in the decline in the improvement of athletes with disabilities for 7-a-side football in the 2020/2021 sports season.
\end{abstract}

Keywords: Corona virus; Football; Disability; Field test.

Cite this article as:

D'Andrea, D., Esposito, G., \& Invernizzi, P.L. (2021). The effects of the COVID-19 pandemic on the training of athletes with disabilities in the 7-a-side football championship. Journal of Human Sport and Exercise, 16(3proc), S1055-S1062. https://doi.org/10.14198/jhse.2021.16.Proc3.23

Corresponding author. University of Salerno, Italy.

E-mail: g.esposito198@studenti.unisa.it

Abstract submitted to: Winter Conferences of Sports Science. Costa Blanca Sports Science Events, 22-23 March 2021. Alicante, Spain.

JOURNAL OF HUMAN SPORT \& EXERCISE ISSN 1988-5202.

(c) Faculty of Education. University of Alicante.

doi:10.14198/jhse.2021.16.Proc3.23 


\section{INTRODUCTION}

Adapted physical activity is part of scientific statement of physical activity and sports sciences (Raiola, 2020ab). In September 2019 a memorandum of understanding was signed in Italy between the Italian Football Federation and the Italian Paralympic Committee, with the aim of developing coordinated action in order to maximize the practice of football for people with disabilities (Martino et al., 2019). This protocol provided for the establishment of a Paralympic and Experimental Football Division with its own operational and organizational structure. It was the first time at an international level that a sports federation dedicated to football, practiced by able-bodied people, foresaw the launch of a specific path for the establishment, internally, of a Federal Division entirely dedicated to Paralympic and experimental football (D'Andrea et al., 2020). This sector, like all others belonging to the world of sport and life in general, has been deeply affected by the effects of the Covid-19 pandemic (Raiola, Di Domenico, 2021, Raiola, Aliberti, 2021, Mon-López et al., 2020). Due to the evolution of the Coronavirus contagion, given the regional ordinances and the indications of the competent Ministry, the Paralympic Football Division has precautionarily suspended activities throughout the national territory. For greater protection of the players, also considering the situation of greater risk due to their more fragile immune systems, the Paralympic division also recommended the suspension of training. The 2020/2021 sports season saw the alternation of training periods carried out on the field in presence, and periods of home training (Mohr et al., 2020). In the first case there was the possibility of carrying out individual training on the field with exercises that did not involve physical contact. Instead, during the home training periods, the training was conducted remotely thanks to the Google Meet platform, where the athletes performed various series of exercises inside their homes with limited space and equipment (Lim et al. 2020). This irregularity and inconstancy during the season certainly did not facilitate the possibility of periodizing the annual training plan. Especially in achieving certain results in terms of aerobic improvement, the improvement of conditional and technical skills (Raiola, 2017, 2015ab, 2013). In addition, it was necessary to consider the disabilities of the athletes, for which it was necessary to carry out regular and constant work in order to raise the performance level and achieve certain objectives (Fitzgerald et al., 2020).

\section{Aim of the study}

The purpose of this study was to verify whether the Covid-19 pandemic produced significant differences in the improvements of athletes with disabilities in 7-a-side football for the 2020/21 season in terms of VO2max, speed and explosive strength. The data were compared with respect to the same parameters detected in a sports season before the pandemic (2018-2019 season).

\section{MATERIALS AND METHODS}

\section{Study participants}

The study was conducted on ten disabled athletes belonging to a football school in Campania. They each had various types of diagnosed disabilities such as Down syndrome, Autism Spectrum Disorder, Intellectual Disability, and Motor Disability. These athletes were not grouped according to age, but according to their functional abilities and their football skills. The athletes covered by this study fell into the category of mediumhigh functionality, that is, they had slight deficits in some basic motor patterns and a good command of football skills.

\section{Study organization}

The athletes were involved in the same annual training plan both for the 2018/19 season, before the Covid19 pandemic, and for the 2020/21 season with the pandemic in progress. Inevitably, in the 2020-2021 season, due to home training, there was a need to resize and recalibrate the objectives of the various training 
macrocycles set at the beginning of the season (Bisciotti et al., 2020; Calandro et al., 2020). In any case, in both sporting seasons taken as a reference, the workouts were structured in such a way as to provide for exercises aimed at improving flexibility and joint mobility at the beginning of the session (Di Domenico, 2020). There are also exercises aimed at developing the strength of the legs, which is essential for effectively carrying out the high number of changes in speed and direction required by a football match. (Esposito et al., 2019; Ceruso et al., 2019). During each workout, through exercises with the ball it was possible to aim at achieving results in terms of improving endurance and speed (Giovanni et al., 2020). Then, following the same process, in an initial evaluation phase held in October, the athletes were subjected to three field tests on entry. The first was Pizzolato's 7-minute test which concerned stamina; the second was the CapannaSassi test which assessed speed combined with resistance, and the third was the long jump test from standing to monitor explosive force (D'Isanto, 2016).

Pizzolato's 7-minute test made it possible to indirectly measure the values of VO2max and SAN, detecting the maximum distance that an athlete could cover in seven minutes, at maximum speed (Izzo et al., 2915). The test can be considered reliable if the speed is kept constant for the entire duration of the effort (Padulo et al., 2012; Pisapia et al., 2018)). The Capanna-Sassi test consisted of repeating a shuttle sprint of $20+20$ meters for 6 times, with a change of direction after the first 20 meters and recovery of 20 seconds between one sprint and the next (Gaetano, 2016). Finally, in the standing long jump test, the subject had to initially position himself with his toes at the edge of the long jump pit. After that he had to make an even-footed jump trying to cover as much horizontal distance as possible (D'Elia et al., 2019). The analysis of the results of the long-standing jump test allowed to establish the explosive elastic force of the athlete's lower limbs and, if referred to previous tests, could give an estimate of the improvements or worsening of performance (D'Isanto et al., 2019).

It is therefore posited as a null hypothesis $(\mathrm{H} 0)$ that at the end of the post-pandemic season there will be no differences in the improvements of these certain physiological characteristics in athletes with respect to the results of the pre-pandemic season, or that they exist but are not significant, and as an alternative hypothesis (H1) that at the end of the season the differences in the improvements of these parameters will be found in such a way as to be certain that they can be attributed to the effects caused from the pandemic. At the end of both sports seasons, these tests were repeated, comparing the data collected with those of the incoming tests through the statistical method of the t-test for dependent samples. This allowed us to analyse the differences between the two data series and establish if they were significant. The null hypothesis $(\mathrm{HO})$ of the study predicted that at the end of the post-pandemic season (2020-2021) there were no significant differences in the improvements of these certain physiological characteristics in athletes compared to the results of the pre-pandemic season (2018-2019). The alternative hypothesis (H1) instead predicted that at the end of the season the differences in the improvements of these parameters were found in such a way as to be able to attribute them to the effects caused by the pandemic.

\section{Statistical analysis}

A paired sample t-test was conducted to combine the results obtained from the test and re-test. The t-test was selected as the analytical method to verify the presence or absence of a significant difference between two sets of data. The significant level has been set at $p<.05$. Statistical analyses were carried out with the software IBM SPSS Statistics 23. 


\section{RESULTS}

Table 1. Pizzolato test season 18/19.

\begin{tabular}{cccccc}
\hline & \multicolumn{2}{c}{ Early season } & \multicolumn{2}{c}{ End of the season } \\
\hline Players & Age & Distance $(\mathrm{m})$ & $\mathrm{VO}_{2 \max }(\mathrm{ml} / \mathrm{kg} / \mathrm{min})$ & Distance $(\mathrm{m})$ & $\mathrm{VO}_{2 \mathrm{max}}(\mathrm{ml} / \mathrm{kg} / \mathrm{min})$ \\
\hline Player 1 & 10 & 1110 & 35.3 & 1146 & 36.2 \\
Player 2 & 12 & 1190 & 37.4 & 1307 & 41.1 \\
Player 3 & 12 & 1145 & 36.2 & 1194 & 37.4 \\
Player 4 & 13 & 1220 & 38.6 & 1373 & 43.3 \\
Player 5 & 11 & 1122 & 35.8 & 1164 & 36.8 \\
Player 6 & 17 & 1101 & 38 & 1358 & 42.6 \\
Player 7 & 10 & 1143 & 36.2 & 1180 & 37.4 \\
Player 8 & 15 & 1257 & 36.8 & 1224 & 38.6 \\
Player 9 & 14 & 1225 & 38.6 & 1393 & 43.3 \\
Player 10 & 13 & 1167 & 36.8 & 1242 & 39.2 \\
\hline
\end{tabular}

Table 2. Pizzolato test season 20/21.

\begin{tabular}{cccccc}
\hline & \multicolumn{2}{c}{ Early season } & \multicolumn{2}{c}{ End of the season } \\
\hline Players & Age & Distance $(\mathrm{m})$ & $\mathrm{VO}_{2 \max }(\mathrm{ml} / \mathrm{kg} / \mathrm{min})$ & Distance $(\mathrm{m})$ & $\mathrm{VO}_{2 \max }(\mathrm{ml} / \mathrm{kg} / \mathrm{min})$ \\
\hline Player 1 & 10 & 1223 & 35.2 & 1180 & 34.3 \\
Player 2 & 12 & 1317 & 40.1 & 1240 & 36.4 \\
Player 3 & 12 & 1214 & 36.4 & 1175 & 35.2 \\
Player 4 & 13 & 1385 & 42.3 & 1255 & 37.6 \\
Player 5 & 11 & 1185 & 35.8 & 1144 & 36.8 \\
Player 6 & 17 & 1245 & 41.6 & 1123 & 37 \\
Player 7 & 10 & 1204 & 36.4 & 1176 & 35.2 \\
Player 8 & 15 & 1298 & 37.6 & 1287 & 35.8 \\
Player 9 & 14 & 1353 & 42.3 & 1256 & 37.6 \\
Player 10 & 13 & 1255 & 38.2 & 1179 & 35.8 \\
\hline
\end{tabular}

Table 3. Capanna-Sassi test season 18/19.

\begin{tabular}{lccc}
\hline Players & Age & Early season Circuit time $\mathbf{( s )}$ & End of the season Circuit time (s) \\
\hline Player 1 & 10 & 7.51 & 7.18 \\
Player 2 & 12 & 8.11 & 7.22 \\
Player 3 & 12 & 7.41 & 7.1 \\
Player 4 & 13 & 7.65 & 7.34 \\
Player 5 & 11 & 7.99 & 7.62 \\
Player 6 & 17 & 7.57 & 7.26 \\
Player 7 & 10 & 7.67 & 7.29 \\
Player 8 & 15 & 7.09 & 6.68 \\
Player 9 & 14 & 7.42 & 7.18 \\
Player 10 & 13 & 7.55 & 7.22 \\
\hline
\end{tabular}


Table 4. Capanna-Sassi test season 20/21.

\begin{tabular}{lccc}
\hline Players & Age & Early season Circuit time (s) & End of the season Circuit time (s) \\
\hline Player 1 & 10 & 7.31 & 7.08 \\
Player 2 & 12 & 7.91 & 7.62 \\
Player 3 & 12 & 7.21 & 6.9 \\
Player 4 & 13 & 7.45 & 7.25 \\
Player 5 & 11 & 7.79 & 7.49 \\
Player 6 & 17 & 7.47 & 7.17 \\
Player 7 & 10 & 7.47 & 7.21 \\
Player 8 & 15 & 6.89 & 7.63 \\
Player 9 & 14 & 7.22 & 7.09 \\
Player 10 & 13 & 7.35 & 7.13 \\
\hline
\end{tabular}

Table 5. Long jump test season 18/19.

\begin{tabular}{lccc}
\hline Players & Age & Early season Jump distance $(\mathbf{c m})$ & End of the season Jump distance $(\mathbf{c m})$ \\
\hline Player 1 & 10 & 63 & 86 \\
Player 2 & 12 & 93 & 120 \\
Player 3 & 12 & 50 & 72 \\
Player 4 & 13 & 170 & 191 \\
Player 5 & 11 & 55 & 56 \\
Player 6 & 17 & 80 & 84 \\
Player 7 & 10 & 45 & 65 \\
Player 8 & 15 & 50 & 73 \\
Player 9 & 14 & 95 & 123 \\
Player 10 & 13 & 58 & 85 \\
\hline
\end{tabular}

Table 6. Long jump test season 20/21.

\begin{tabular}{lccc}
\hline Players & Age & Early season Jump distance $(\mathbf{c m})$ & End of the season Jump distance (cm) \\
\hline Player 1 & 10 & 69 & 80 \\
Player 2 & 12 & 97 & 108 \\
Player 3 & 12 & 55 & 66 \\
Player 4 & 13 & 178 & 186 \\
Player 5 & 11 & 59 & 68 \\
Player 6 & 17 & 87 & 97 \\
Player 7 & 10 & 49 & 58 \\
Player 8 & 15 & 56 & 62 \\
Player 9 & 14 & 101 & 109 \\
Player 10 & 13 & 67 & 76 \\
\hline
\end{tabular}


Table 7. T-test for dependent samples.

\begin{tabular}{|c|c|c|c|c|c|c|c|c|}
\hline \multicolumn{9}{|l|}{ Paired Samples Test } \\
\hline & \multicolumn{5}{|c|}{ Paired Differences } & \multirow{3}{*}{$t$} & \multirow{3}{*}{$d f$} & \multirow{3}{*}{ Sig. (2-tailed) } \\
\hline & \multirow[t]{2}{*}{ Mean } & \multirow{2}{*}{$\begin{array}{l}\text { Std. } \\
\text { Deviation }\end{array}$} & \multirow{2}{*}{$\begin{array}{l}\text { Std. Error } \\
\text { Mean }\end{array}$} & \multicolumn{2}{|c|}{$\begin{array}{l}\text { 95\% Confidence Interval } \\
\text { of the Difference }\end{array}$} & & & \\
\hline & & & & Lower & Upper & & & \\
\hline $\begin{array}{l}\text { Pizzolato } 18-19 \text { pre - } \\
\text { Pizzolato } 18-19 \text { post }\end{array}$ & -90.1000 & 84.15257 & 26.61138 & -150.29912 & -29.90088 & -3.386 & \multirow[b]{2}{*}{9} & .008 \\
\hline $\begin{array}{l}\text { Pizzolato } 20-21 \text { pre - } \\
\text { Pizzolato } 20-21 \text { post }\end{array}$ & 66.4000 & 40.50295 & 12.80816 & 37.42594 & 95.37406 & 5.184 & & .001 \\
\hline $\begin{array}{l}\text { Capanna } 18-19 \text { pre - } \\
\text { Capanna } 18-19 \text { post }\end{array}$ & .33800 & .05029 & .01590 & .30203 & .37397 & 21.255 & 9 & .000 \\
\hline $\begin{array}{l}\text { Capanna 20-21 pre - } \\
\text { Capanna 20-21 post }\end{array}$ & .15000 & .31774 & .10048 & -.07729 & .37729 & 1.493 & 9 & .170 \\
\hline $\begin{array}{l}\text { Long jump 18-19 pre - } \\
\text { Long jump 18-19 post }\end{array}$ & -19.60000 & 9.43045 & 2.98217 & -26.34614 & -12.85386 & -6.572 & 9 & .000 \\
\hline $\begin{array}{l}\text { Long jump 20-21 pre - } \\
\text { Long jump 20-21 post }\end{array}$ & -9.20000 & 1.61933 & .51208 & -10.35840 & -8.04160 & $\begin{array}{l}- \\
17.966\end{array}$ & 9 & .000 \\
\hline
\end{tabular}

\section{DISCUSSION}

From the analysis of the data using the t-test for dependent samples it was possible to appreciate, compared to the $18 / 19$ season, the existence of a statistically significant difference both for the Pizzolato test $(p=.008)$ and for the Capanna test $(p=.000)$ and the long jump test $(p=.000)$. Instead, taking into consideration the data of the 20/21 season, a significant difference was found only for the Pizzolato test $(p=.001)$ and for the long jump test $(p=.000)$. There was no significant difference for the Capanna test $(p>.05)$. By comparing, through these results, the differences between the improvements due to training between the pre-pandemic $18 / 19$ season and the post-pandemic $20 / 21$ season, it is possible to reject $\mathrm{H} 0$ and accept $\mathrm{H} 1$ for all three tests considered, given that it tests carried out for the post-pandemic season did not reveal significant differences in the improvements of the athletes as was the case for the pre-pandemic season (D'Elia et al., 2020, Raiola et al., 2020ab). For all three cases it can therefore be established, according to what was the objective of the study, that there are differences between the improvements found at the end of the two seasons with respect to the initial parameters that can be attributed the effects caused by the Covid-19 pandemic (Turk \& McDermott, 2020). Translating these results into practical terms, we can underline that the study we conducted proved useful for all the goals that were set. Among the main limitations of this study is the small number of participants to which it was subjected and, above all, the impossibility of having adequate scientific evidence in the literature regarding its veracity, considering the uniqueness of the current historical period. The present study still offers various possibilities for development in the future such as, for example, the increase in the sample size and the addition of further tests aimed at finding significant differences also, regarding football skills.

\section{CONCLUSION}

In conclusion, we can say that the Covid-19 pandemic has had such significant implications in the lives of athletes, especially for distancing and social isolation that have led to the need to carry out spaced workouts or even from home, as to have impacted in a way significant on training planning and on the improvements obtained by athletes in the 20/21 season compared to the $18 / 19$ one. This consideration applies both to the increase in Vo2max and to speed and muscle strength. 


\section{REFERENCES}

Bisciotti, G. N., Eirale, C., Corsini, A., Baudot, C., Saillant, G., \& Chalabi, H. (2020). Return to football training and competition after lockdown caused by the COVID-19 pandemic: medical recommendations. Biology of Sport, 37(3), 313. https://doi.org/10.5114/biolsport.2020.96652

Calandro, A., Esposito, G., Altavilla, G. (2020) Intermittent training and improvement of anthropometric parameters and aerobic capacity in youth football. Journal of Human Sport and Exercise, 15, S599S608. https://doi.org/10.14198/ihse.2020.15.Proc3.12

Cataldi, S., Francavilla, V.C., Bonavolontà, V., De Florio, O., Carvutto, R., De Candia, M., Latino, F., Fischetti, F. (2021). Proposal for a fitness program in the school setting during the covid 19 pandemic: Effects of an 8-week crossfit program on psychophysical well-being in healthy adolescents, International Journal of Environmental Research and Public Health, 18 (6), art. no. 3141, pp. 1-12. https://doi.org/10.3390/ijerph18063141

Ceruso, R., Esposito, G., D'Elia, F. (2019) Analysis and evaluation of the qualitative aspects of the young players. Journal of Physical Education and Sport, 19, art. no. 266, pp. 1814-1819.

D'Andrea, D., Scurati, R., Izzo, R., Invernizzi, P. L., \& D'Isanto, T. (2021). Football the performance level of athletes with disabilities for the" fourth category" 7-a-side championship. Journal of Human Sport and Exercise, 16(2), 743-751. https://doi.org/10.14198/ihse.2021.16.Proc2.60

D'Elia, D., Domenico, F.D., Isanto, T.D., Altavilla, G., Raiola, G. (2020) From biomechanics to motor learning, Acta Medica Mediterranea, 36 (5), pp. 3073-3078.

D'Elia, F., D'Isanto, T., Altavilla, G. (2019) Training and performance in the transition period. Journal of Human Sport and Exercise, 14 (Proc2), pp. S258-S262. https://doi.org/10.14198/ihse.2019.14.Proc2.15

Di Domenico, F. (2020) From biomechanics to learning: Continuum for the theory of physical and sports education. Journal of Human Sport and Exercise, 15 (Proc2), S268-S278. https://doi.org/10.14198/ihse.2020.15.Proc2.18

D'santo, T. (2016) Pedagogical value of the body and physical activity in childhood [Pedagoška vrijednost tijela i tjelesne aktivnosti u djetinjstvu]. Sport Science, 9, 13-18.

D'Isanto, T., D'Elia, F., Raiola, G., Altavilla, G. (2019) Assessment of sport performance: Theoretical aspects and practical indications. Sport Mont, 17 (1), 79-82. https://doi.org/10.26773/smj.190214

Fitzgerald, H., Stride, A., Drury, S. (2020). COVID-19, lockdown and (disability) sport. Managing Sport and Leisure, 1-8. https://doi.org/10.1080/23750472.2020.1776950

Gaetano, A. (2016) Relationship between physical inactivity and effects on individual health status, Journal of Physical Education and Sport, 16, 1069-1074.

Giovanni, E., Francesca, D., Gaetano, R. (2020). A method to promote the Development of intelligence and game skills in youth football. Teoria ta Metodika Fizicnogo Vihovanna, 20 (3), pp. 142-148. https://doi.org/10.17309/tmfv.2020.3.03

Izzo, R., Lo Castro, L. (2015). The study of acceleration and deceleration capacity decrease in repeated sprints in soccer. International Journal of Physical Education, Sport and Health, 2(2), 2394-1685.

Lim, M. A., Pranata, R. (2020). Sports activities during any pandemic lockdown. Irish Journal of Medical Science (1971-), 1-5. https://doi.org/10.1007/s11845-020-02300-9

Martino, L., Fonzo, E., Cassese, F. P., \& D'santo, T. (2019). Principles of adaptation of the rules for disabled athletes for an inclusion sport. Journal of Human Sport \& Exercise, 14(2), 215-220. https://doi.org/10.14198/ihse.2019.14.Proc2.08

Mohr, M., Nassis, G. P., Brito, J., Randers, M. B., Castagna, C., Parnell, D., \& Krustrup, P. (2020). Return to elite football after the COVID-19 lockdown. Managing Sport and Leisure, 1-9. https://doi.org/10.1080/23750472.2020.1768635 
Mon-López, D., García-Aliaga, A., Bartolomé, A. G., Solana, D. M. (2020). How has COVID-19 modified training and mood in professional and non-professional football players?. Physiology \& behavior, 227, 113148. https://doi.org/10.1016/i.physbeh.2020.113148

Padulo, J., D'Ottavio, S., Pizzolato, F., Smith, L., Annino, G. (2012). Kinematic analysis of soccer players in shuttle running. International journal of sports medicine, 33(6), 459. https://doi.org/10.1055/s0032-1304641

Pisapia, F., D'Isanto, T. (2018) Inclusive methods of adaptive training in sprints: A theoretical preliminary study. Journal of Physical Education and Sport, 18, art. no. 316, 2101-2105.

Raiola, G., Aliberti, S., Esposito, G., Altavilla, G., D'Isanto, T., \& D'Elia, F. (2020a). How has the Practice of Physical Activity Changed During the COVID-19 Quarantine? A Preliminary Survey. Teoriâ Ta Metodika Fizičnogo Vihovannâ, 20(4), 242-247. https://doi.org/10.17309/tmfv.2020.4.07

Raiola, G., Domenico, F.D., Isanto, T.D., Altavilla, G., Elia, F.D. (2020b) Biomechanics core, Acta Medica Mediterranea, 36 (5), pp. 3079-3083.

Raiola, G., Di Domenico, F. (2021) Physical and sports activity during the COVID-19 pandemic, Journal of Physical Education and Sport, 21, pp. 477-482.

Raiola, G., Aliberti, S. (2021) Outdoor sports and physical activity during social distancing by sports sciences and exercise course students at the university of Salerno, Journal of Physical Education and Sport, 21, pp. 612-617.

Raiola, G. (2020a). Proposal of rearrangement of physical training and sport sciences methodology academic disciplines in Italian university body. Sport Science, 14 (1): 43-47.

Raiola, G. (2020b). The Movement and Sport Science in Italy towards the European Research Council. Physical Culture and Sport, Studies and Research, 86 (1):37-48. https://doi.org/10.2478/pcssr-20200011

Raiola, G. (2019) Comparison of exercise and sport sciences epistemology between european research council structure panel and Italian academic system, Sport Science, 12, pp. 112-120.

Raiola, G. Motor learning and teaching method (2017) Journal of Physical Education and Sport, 17, art. no. 236, pp. 2239-2243.

Raiola, G. (2015a) Inclusion in sport dance and self perception, Sport Science, 8, pp. 99-102.

Raiola, G. (2015b) Sport skills and mental health, Journal of Human Sport and Exercise, 10 (Specialissue), pp. S369-S376. https://doi.org/10.14198/hhse.2015.10.Proc1.27

Raiola, G. (2013) Body knowledge and motor skills, Knowledge Cultures, 1 (6), pp. 64-72.

Turk, M. A., \& McDermott, S. (2020). The COVID-19 pandemic and people with disability. Disability and Health Journal, 13(3). https://doi.org/10.1016/i.dhjo.2020.100944

\section{@)}

This work is licensed under a Attribution-NonCommercial-NoDerivatives 4.0 International (CC BY-NC-ND 4.0). 